\title{
Domestic Tourism as a Factor of Survival and Recovery of Tourism in the V4 Countries (a comparative study)
}

\author{
DOI 10.18267/pr.2021.krn.4816.13
}

\author{
Zuzana Kvítková ${ }^{1}$ - Zdenka Petrů2 \\ ORCID iD: 0000-0002-4851-2182 ${ }^{1}, 0000-0002-5269-2091^{2}$ \\ lechyno@vse.cz, petru@vse.cz \\ 1,2Prague University of Economics and Business, FIR, Tourism Department, \\ Prague, Czech Republic
}

\begin{abstract}
From review of the official tourism authorities' documents and analysis (UNWTO, WTTC) comes out that domestic tourism is one the key factors of tourism businesses survival and the first step to recovery. The paper aims to map and characterize the current state of tourism of the V4 countries and to compare the potential of domestic tourism as a factor of survival and tourism recovery after COVID-19 pandemic. The methodology of the paper is based on comprehensive data analysis, descriptive statistics and comparison of the economical and tourism indicators and results. The paper combines different sources of data in order to analyse the situation from more perspectives. The results reveal that the best position of domestic tourism is in Slovakia and the Czech Republic. In both countries, the scorecard demonstrates the high potential of domestic tourism to be a significant factor of business survival and tourism recovery.
\end{abstract}

Keywords: tourism, tourism recovery, V4 group, COVID-19 pandemic

JEL Classification codes: L83, O57, Z30

\section{INTRODUCTION}

Global tourism according to the data from the World Tourism Organization (UNWTO) (2021a) suffered its deepest crises in history with a drop of 74\% in 2020 in international arrivals (1 billion fewer) in comparison with the previous year 2019 due to the outbreak of the COVID-19 pandemic. This happened due to an unprecedented fall in demand and widespread travel restrictions. The impact of global economic crises (2008) during the year 2009 was only of the $4 \%$ decline in international arrivals. The collapse in international tourism represented also an estimated loss of USD 1.3 trillion in export revenues, which is more than 11 times the loss recorded during the year 2009 global economic crisis. This new health, social and economic crisis had also put between 100 and 120 million direct tourism jobs at risk, many of them in micro, small and medium-sized enterprises. All world regions and sub-regions were affected. In a short period, global tourism market faced the shift from overtourism (Diaz Parra, 2020) to non-tourism and the negative impact on the tourism and hospitality value chain (Gössling et al, 2020), which collapsed. Europe recorded a 70\% decrease in arrivals in 2020 in comparison with 2019, despite a small and short-lived revival in the summer of 2020. The region suffered the largest drop in absolute terms, with over 500 million fewer international tourists in 2020 than in 2019 (UNWTO, 2021a). The more dependent the region, sub-region, or country itself are on international arrivals, the more they were impacted. Domestic tourism as well as intraregional tourism in many regions, subregions, and countries, plays a very important role in the pandemic and post-pandemic Covid-19 period. Both are considered to be 
a recovery driver (Euromonitor, 2021) or an emergency exit in 2020, but will probably continue for 2021 as the COVID-19 crisis is far from over.

This paper brings the comparison of countries, which are members of the Visegrad Group (also known as the "Visegrad Four" or simply "V4"). V4 is the important regional grouping of the four Central European states: Czech Republic, Hungary, Poland, and Slovakia. It was established in 1991 when the V4 member states signed a declaration of close cooperation on the path to European integration (MV CR, 2019). Today, all V4 countries are members of the EU and focus on promoting cooperation and stability in the wider Central European region. The V4 countries have many common features: history, economy, interests, but also many differences. It also appears in the field of tourism. According to the UNWTO (2020a) regional division, the V4 countries belong to the Central / Eastern Europe subregion.

\section{LITERATURE REVIEW}

\subsection{Factors of (domestic) tourism 's development}

The most frequently mentioned factors (Horner 1996, Palatkova 2006, Petru 2007) that affect tourism are mainly the political situation of the country, as well as economic, demographic, ecological, legislative, social, or material-technical factors. All these factors also operate in domestic tourism (Lim, 1997). In many countries, domestic tourism is dominant concerning with respect to international flows, in terms of both size and economic contribution (Massidda, 2012). One of the most important factors is, of course, the income of the population as an economic factor. Seddighi and Shearing (1997) and Garin-Munoz (2009) find that relative real income is one of the main determinants of domestic tourism. The effect is positive till a certain level though some research reveals that the inhabitants with growing incomes prefer foreign destinations to their home country (Athanasopoulos and Hyndman, 2008). Among noneconomic factors, it is the motivation of travellers associated primarily with the natural and cultural-historical attractions of the country/destination. Motivation is one of the most important elements in the decision-making process (Swarbrook, 2007). The country's attractiveness is measured using the TTCI (Travel and Tourism Competitiveness Index). This research took into account the sub-index of natural and cultural resources. When choosing a destination, it is crucial that potential travellers feel safe. According to Holloway (2012), safety and security are also essential when it comes to the image of a tourist destination and the satisfaction of visitors. During the COVID-19 pandemic, the issue of health security plays a very important role in choosing a destination. The restrictions and hygiene standards were similar in all V4 countries and the health care systems are well developed. During the COVID19 crisis, travellers prefer their own country when choosing a holiday, where they know the security risk better.

According to UNWTO (2020a) domestic tourism is over six times larger than international tourism (in numbers of overnight trips). Domestic tourism expenditure is higher than inbound spending in most large destinations. Statistical data do not include same-day trips, visits of friends and relatives as well as holidays/trips to second homes (private cottages, private countryside houses). Owning second homes or cottages greatly contributes to the development of domestic tourism outside its commercial form. Domestic tourism in this form is very developed, for example, in Sweden and France (Horner, 1996), as well as in the Czech Republic.

The literature focuses on the demand side of the market - tourists' motivation to spend holidays in their home country or the role of satisfaction. The situation in summer 2020 is unique. This research is putting together the macroeconomic criteria and tourism statistics. 


\subsection{Impact of the crisis on the tourism}

Coronavirus disease (COVID-19) dominated 2020. As the year 2020 ended globally (WHO, 2021a) cases rose to 83,326,479 cases and 1,831,703 deaths. In both cases, Europe's share of these figures was 32\%. The disease started in January 2020 in China. In March 2020, it continued to all continents in the world (in 146 countries), the spread slowed down in the summer period, and returned in the second wave in autumn 2020. By the end of 2020, the vaccines arrived but challenges continued as new COVID-19 strains appeared (AJMC, 2021). These can cause re-infection and faster spread of the virus in 2021. In 2020 international, regional, and local travel restrictions immediately affected national economics, including tourism systems, e. g. international travel, domestic tourism, and segments as air transport, cruises, accommodation, cafés and restaurants, conventions, festivals, meetings, or sports events. As a result of the pandemic, many countries (UNWTO, 2020b) imposed travel bans, closed borders, or introduced quarantine periods, which caused a decline of both international and domestic tourism. Until 2019 according to UNWTO (2020a), tourism was the key economic sector in many advanced and emerging economies. Tourism was also one of the largest and fastest-growing economic sectors in the world. Since 2017 the global picture of travel and tourism growth forecast was as 4\% for each year for the following ten years (WTTC, 2017) that lasted until 2019. All this was happening despite terrorist attacks and political instabilities, health pandemic, and natural disasters. International tourism institutions and the tourism sector itself could not imagine a global health pandemic with such far-reaching consequences. An unprecedented tourism situation emerged: from a forecasted good 2020 season to an almost lost season and rather bleak prospects for the years thereafter (Gössling et al., 2020). Global tourism was the most affected economic sector by the COVID-19 pandemic, but on the other hand, due to the tourism globalisation, the COVID-19 has spread worldwide in a pandemic.

\subsection{Recovery of tourism - strategies, possibilities, recommendations}

The COVID-19 pandemic in 2020 was in two waves, and all countries and their governments were adopting their lockdowns. The majority of European countries were closing their economies in March 2020 with reopening in the middle or end of June 2020, having the short revival in summer months and new closures in September/October 2020 lasting till the end of 2020, and onwards. There were adopting measures for the economy and tourism recovery taking into consideration recommendations and guidelines of international bodies.

International institutions (WHO, OECD, European Commission) and tourism organizations (UNWTO, WTTC, ETC) during the year 2020 were coming with health recommendations and guidelines for recovery, different types of support of economies including the tourism industry. WHO (World Health Organization) concentrated its attention on health and security information, guidelines, and recommendation for travel (especially air travel), for workers, and staying at hotels and other accommodation establishments. At the European Union level, there is enhanced the role of regions, both in EU programmes (especially ERDF) as in national plans of EU member states. At the level of the EU, there will not be any direct fund for tourism in the new programming period 2021-2027 (Houska, 2019). Recommendation of EU (EC, 2020a) for state aid were including direct grants, selective tax advantages, and advance payments, state guarantees for loans taken by companies from banks, subsidised public loans to companies, safeguards for banks that channel State aid to the real economy, short-term export credit insurance. Most tourism businesses (around $80 \%$ ) are micro, small, and medium-sized (UNWTO, 2020a), which means that it was sometimes difficult for them to reach these supports. In EU guidance (EC, 2020b) is stated, that citizens should be connected to local 
tourism offer and local attractions should be promoted. A voucher system was recommended to support tour operators, local hotels, and restaurants.

Among UNWTO's (2020b) recommendations for recovery and resilience of tourism, they are such responsible travel, solidarity, and supporting recovery. In UNWTO (2020b) COVID-19 tourism recovery package has mentioned the importance of domestic tourism for the recovery including a specific recommendation for domestic tourism marketing strategy with the important role of DMO (Destination Management Companies). WTTC (2020b) emphasizes the importance of safety in the tourism sector, even if $100 \%$ safety cannot be guaranteed. WTTC in cooperation with experts created protocols taking into account WHO (2020b) and CDC guidelines (2020) in general and for different sectors of the tourism industry (e.g. hospitality, airports, tour operators, attractions, etc.). The ETC, European Travel Commission (2020b) supported all measures to facilitate travel in Europe. The aim is to create a sustainable future for the travel and tourism ecosystem, to create a more resilient and sustainable destination Europe in the future. According to the ETC (2021), the vaccine roll-out and improved testing and tracing regime will provide some grounds for optimism for a gradual recovery in 2021. Nevertheless, the return to the typical international demand pattern will be gradual with 2019 levels predicted to return by 2023. The return to travel will, however, happen with new consumer habits, calling for strong adaptation and agile responses from the tourism sector. Ensuring safe travel opportunities should become a priority for destinations as potential travellers are likely to travel more slowly, closer to home, and lesser-known destinations. A quicker easing of restrictions for domestic travel and stronger demand from residents to travel locally provides some support to those hotels that remained open; however, a second wave of the COVID-19 outbreak placed a halt to the travel rebound.

Domestic tourism, which accounts for around $75 \%$ of the tourism economy in OECD countries (OECD, 2020), as expected will recover more quickly after the COVID-19 pandemic. According to Euromonitor International research (2021), there will be a permanent change in consumer behaviour. Domestic tourism expenditures and average spend per trip in 2019-2024 will go up. Domestic tourism expenditure as a total \% of the tourism in 2020 was $73 \%$ (e.g., in China, U.S.A), up 9\% in 2019. One of the key takeaways of this survey was, that in the short to mid- term, there will be more away from international travel to destinations closer to home with domestic tourism as a recovery driver.

\section{METHODOLOGY}

The paper aims to map and characterize the current state of tourism of the V4 countries and to compare the potential of domestic tourism as a factor of survival and its potential for tourism recovery after the COVID-19 pandemic.

The methodology of the paper is based on comprehensive data analysis, descriptive statistics, and comparison of the economical and tourism indicators and results. The paper combines different sources of data to analyse the situation from more perspectives. The sources were chosen and combined with regard to the availability of the data. The following data sources are used: World Bank, Eurostat, World Tourism and Travel Council (WTTC), World Tourism Organisation (UNWTO), Statistical offices of the individual countries, World Economic Forum (WEF).

To reach the aim of the paper, the following research questions are set:

(1) What was the state of international and domestic tourism in the V4 countries before the COVID-19 pandemic?

(2) What is the impact of the pandemic and the restrictions on international and domestic tourism? 
(3) What is reaction of the international and domestic markets in case the restrictions are being eased?

(4) What is the potential of domestic tourism as a factor of survival and recovery of tourism?

Data from different sources are analysed, and domestic tourism and its potential are assessed from several points of view to answer these questions. A descriptive statistic is used to analyse the data that are relevant to the aim of the paper and an overall picture of the situation in tourism is described. As evaluation method a scorecard with an order of the countries in individual criteria was chosen. The robustness of the scorecard was examined in two ways to assure the relevance of research results. The first way includes the expert estimate of the weights based on the expected importance (1-10); the second way of testing was the number of ranks 1 and 2 in the criteria.

Even though the source methodologies differ, the individual comparisons of the indicators draw data from the same source. The only exception is data from the countries' statistical offices and which follow the recommended UNWTO methodology.

\section{RESULTS AND DISCUSSION}

\subsection{Basic and economic indicators of V4 countries}

This section brings an insight into the general characteristics and economic performance of the countries. It provides important information for the following analysis. The four countries are different in terms of number of inhabitants; however, they are similar in terms of economic performance. The purchasing power of the inhabitants expressed as GDP per capita is between EUR 14.889 and EUR 20,910. Compared to Germany (as an important source country), the V4 counties' purchasing power is still at around 35\% of German level.

Tab. 1 Basic and economic indicators

\begin{tabular}{|l|l|l|l|l|}
\hline & $\begin{array}{l}\text { Number of } \\
\text { inhabitants } \\
\text { (million) }\end{array}$ & $\begin{array}{l}\text { GDP (2019) } \\
\text { (billion euros) }\end{array}$ & $\begin{array}{l}\text { GDP per capita } \\
\text { in EUR (2019) }\end{array}$ & $\begin{array}{l}\text { Unemployment } \\
\text { rate - July } \\
\text { 2020, in \% }\end{array}$ \\
\hline Czech Republic & 10.71 & 223.95 & $20,910.4$ & 2,7 \\
\hline Slovakia & 5.46 & 94.17 & $17,247.3$ & 6,8 \\
\hline Poland & 37.85 & 529.03 & $13,977.0$ & 3,2 \\
\hline Hungary & 9.66 & 143.83 & $14,889.2$ & 7,2 \\
\hline
\end{tabular}

Source: World Bank, Statista.com, own calculations

For assessing the potential of domestic tourism, we will take the GDP per capita into account. As the price levels in the countries are similar, the better the financial situation of the residents is, the more they can spend on travel.

\subsection{Tourism in V4 countries from the economic perspective}

Various sources of information are used for evaluation of the economic effect of tourism in the researched countries. The up-to-date data are not available in all sources. Most of the data is 
drawn from the WTTC, if a deeper insight is required, the TSAs (Tourism satellite accounts) of the individual countries are used.

Tab. 2 Tourism indicators - economic performance

\begin{tabular}{|l|l|l|l|}
\hline & $\begin{array}{l}\text { Direct tourism } \\
\text { contribution to GDP in } \\
\%(2018)\end{array}$ & $\begin{array}{l}\text { Total tourism } \\
\text { contribution to GDP in } \\
\%(2019)\end{array}$ & $\begin{array}{l}\text { Tourism contribution } \\
\text { to export in \% in } \\
(2019)\end{array}$ \\
\hline Czech Republic & 2.7 & 6.5 & 4.1 \\
\hline Slovakia & 2.6 & 6.3 & 3.0 \\
\hline Poland & 1.9 & 4.7 & 4.4 \\
\hline Hungary & 2.6 & 8.3 & 6.4 \\
\hline
\end{tabular}

Source: WTTC (2020), WTTC (2019), WEF (The Travel \& Tourism Competitiveness Report 2019)

Tourism is in V4 countries an important part of the economy. Even if the direct contributions to the GDPs are not that significant (between 1.9\% in Poland and $2.7 \%$ in the Czech Republic) (WEF, 2019), tourism is an important sector due to the multiplication effect. According to WTTC's Economic Impact Reports, the total travel and tourism's contribution to GDP was in 2019 between $4.7 \%$ (in Poland) and 8.3\% (in Hungary). In Slovakia, it was 6.3\% and in the Czech Republic, it was $6.5 \%$. The total (direct and indirect) effect is taken into account (WTTC, 2020).

Inbound tourism is part of export (so-called invisible export) and in the V4 countries it creates between 3\% (Slovakia) and $6.4 \%$ (Hungary) of the national exports. The next figure shows the distribution of travel and tourism's contribution to GDP. In the V4 countries, the share of domestic tourism's contribution is between $34 \%$ and $44 \%$. The main part of the contribution is in all countries produced by inbound tourism.

Fig. 1 Distribution of travel and tourism direct contribution to GDP in 2017 (\%) - TSA

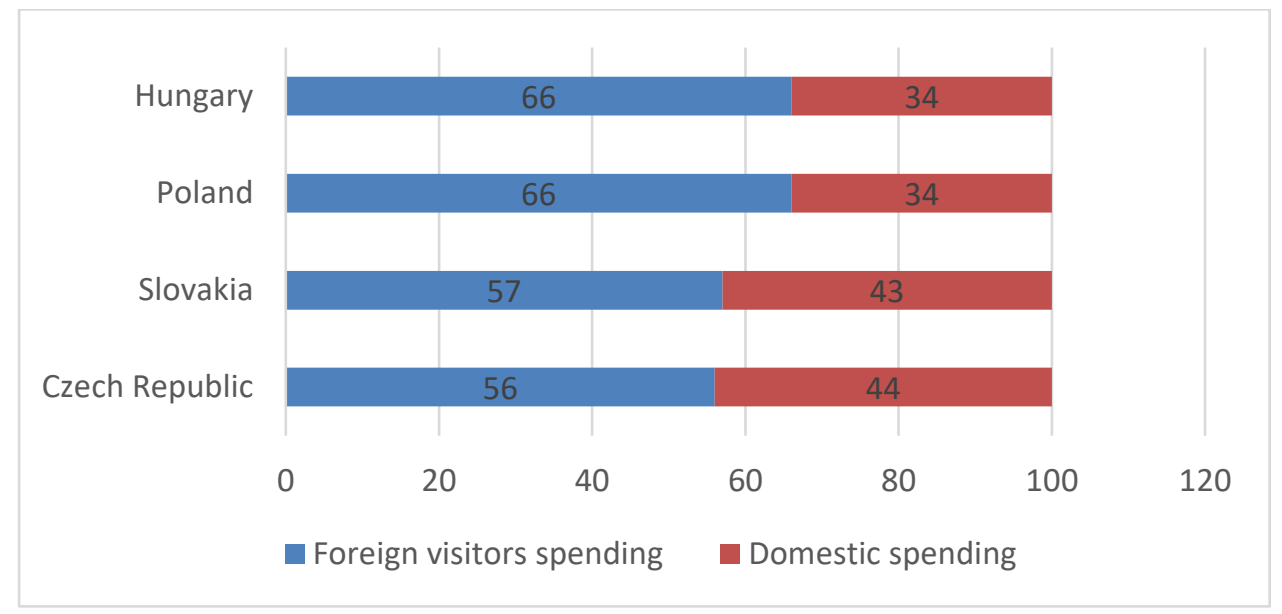

Source: Eurostat, Data collection on TSA 2019

Worldwide the division of expenditures is significantly different: international tourism creates only $28.7 \%$ and domestic tourism $71.3 \%$ (WTTC, 2020, Travel \& Tourism - Global Economic Impact \& Trends 2020). 
To evaluate the potential of domestic tourism for survival and recovery after the COVID-19 pandemic, it is important to know the financial results and comparison of inbound, domestic, and outbound tourism.

Tab. 3 Tourism indicators - financial performance

\begin{tabular}{|l|l|l|l|}
\hline & $\begin{array}{l}\text { Inbound tourism } \\
\text { expenditures (million } \\
\text { EUR) TSA-2017 }\end{array}$ & $\begin{array}{l}\text { Domestic tourism } \\
\text { expenditures (million } \\
\text { EUR) TSA-2017 }\end{array}$ & $\begin{array}{l}\text { Outbound tourism } \\
\text { expenditure (million } \\
\text { EUR) TSA-2017 }\end{array}$ \\
\hline Czech Republic & 6.263 & 4.485 & 2.867 \\
\hline Slovakia & 2.465 & 1.870 & 1.314 \\
\hline Poland & 8.446 & 4.380 & 3.145 \\
\hline Hungary & 4.147 & 2.146 & 2.208 \\
\hline
\end{tabular}

Source: Eurostat (2019). Tourism Satellite Accounts in Europe, 2019 edition

All countries have a positive balance in regard to tourism expenditures. The foreign tourists coming to the V4 counties spend more money than the residents when going abroad. This fact indicates that it will be difficult to replace the inbound expenditure with an increase in domestic tourism.

\subsection{Tourism in V4 countries}

All the countries have a similar history - communist regime - and international tourism started developing in a larger scale after the revolution in 1989. The countries had to go a long way to their nowadays position. From the TTCI (Travel \& Tourism Competitiveness Index) results that the most competitive country is the Czech Republic, followed by Poland, Hungary, and Slovakia. The index consists of four areas; in terms of country attractiveness for residents, the most important will be the natural and cultural resources (based on the prevailing motivation). From this point of view, Poland is the most competitive country.

Tab. 4 Travel \& Tourism Competitiveness Index - 2019

\begin{tabular}{|l|l|l|l|l|l|}
\hline & $\begin{array}{l}\text { TTCI } \\
\text { position } \\
\text { (from 140) }\end{array}$ & $\begin{array}{l}\text { TCI score } \\
\text { (max. 7) }\end{array}$ & $\begin{array}{l}\text { Natural } \\
\text { resources } \\
\text { score }\end{array}$ & $\begin{array}{l}\text { Cultural } \\
\text { resources } \\
\text { score }\end{array}$ & $\begin{array}{l}\text { Natural and } \\
\text { cultural } \\
\text { resources }\end{array}$ \\
\hline Czech Republic & 38 & 4,3 & 2.5 & 2.4 & 2.5 \\
\hline Slovakia & 60 & 4 & 3.4 & 1.6 & 2.5 \\
\hline Poland & 42 & 4,2 & 3.2 & 3.0 & 3.1 \\
\hline Hungary & 48 & 4,2 & 2.7 & 2.3 & 2.5 \\
\hline
\end{tabular}

Source: World Economic Forum, (https://reports.weforum.org/travel-and-tourism-competitivenessreport-2019/)

The highest number of collective accommodation establishments (CAE) is in Poland $(11,251)$ (https://stat.gov.pl), followed by the Czech Republic $(9,383)$ (www.czso.cz), Slovakia (www.statistics.sk) and Hungary $(3,475)$ (www.ksh.hu). When we have a look at the number of rooms and beds, the situation slightly changes due to larger hotels on average in Hungary. 
The next table shows the number of tourists in CAE and reveals also the proportion between international and domestic tourists. The larger the share of domestic tourists in the $C A E$, the smaller the gap in occupancy when the international tourism is restricted.

Tab. 5 Tourist arrivals at CAE - 2019

\begin{tabular}{|l|l|l|l|l|l|}
\hline & $\begin{array}{l}\text { Tourist } \\
\text { arrivals at } \\
\text { CAE total in } \\
2019 \text { (million) }\end{array}$ & $\begin{array}{l}\text { International } \\
\text { tourist arrivals } \\
\text { at CAE in } \\
2019 \text { (million) }\end{array}$ & $\begin{array}{l}\text { Domestic } \\
\text { tourist arrivals } \\
\text { at CAE in } \\
2019 \text { (million) }\end{array}$ & $\begin{array}{l}\text { Share of } \\
\text { domestic } \\
\text { tourists in } \\
\text { CAE (\%) }\end{array}$ & $\begin{array}{l}\text { Tourism } \\
\text { intensity } \\
\text { (overnights / } \\
\text { inhabitant) }\end{array}$ \\
\hline Czech Republic & 20.698 & 9.590 & 11.108 & 53.7 & 5.34 \\
\hline Slovakia & 6.483 & 2.475 & 3.957 & 61.0 & 2.04 \\
\hline Poland & 35.668 & 7.471 & 28.198 & 79.1 & $2.34(2018)$ \\
\hline Hungary & 12.920 & 6.169 & 6.751 & 52.3 & 3.22 \\
\hline
\end{tabular}

Source: Eurostat, own calculations, Tourdata.cz, statista.com

All the V4 countries have more than $50 \%$ of residents in the $C A E$, in Poland the residents create even $79.1 \%$. Tourism intensity is the ratio of nights spent at CAE relative to the total inhabitants of the country. The highest tourism intensity is in the Czech Republic. The higher the ratio, the more difficult will be to fill the capacity with only domestic tourists.

\subsection{Tourism in V4 countries in 2020}

The impact of the pandemic on tourism is devastating. Even if the governments support the businesses, the subsidy usually does not cover the costs. This section reveals the extent to which tourism in these countries has been affected by the COVID-19 pandemic. The table brings the results regarding the number of tourists in CAE. In all V4 countries, the number of guests in CAE dramatically dropped down.

Tab. 6 Tourist arrivals at CAE - analysis of available results from 2020 (in million)

\begin{tabular}{|l|l|l|l|l|l|l|}
\hline & $\begin{array}{l}\text { Tourist } \\
\text { arrivals at } \\
\text { CAE total }\end{array}$ & $\begin{array}{l}\text { Index } \\
2020 / \\
2019\end{array}$ & $\begin{array}{l}\text { International } \\
\text { tourist arrivals } \\
\text { at CAE }\end{array}$ & $\begin{array}{l}\text { Index } \\
2020 / \\
2019\end{array}$ & $\begin{array}{l}\text { Domestic } \\
\text { tourist arrivals } \\
\text { at CAE }\end{array}$ & $\begin{array}{l}\text { Index } \\
2020 / \\
2019\end{array}$ \\
\hline $\begin{array}{l}\text { Czech Republic (till } \\
\text { 9/2020) }\end{array}$ & 10.070 & 0.581 & 2.658 & 0.321 & 7.411 & 0.821 \\
\hline $\begin{array}{l}\text { Slovakia (till } \\
8 / 2020)\end{array}$ & 2.575 & 0.590 & 0.734 & 0.429 & 1.841 & 0.695 \\
\hline Poland (till 9/2020) & 15.455 & 0.556 & 1.986 & 0.345 & 13.466 & 0.611 \\
\hline $\begin{array}{l}\text { Hungary (till } \\
12 / 2020)\end{array}$ & 5.182 & 0.401 & 1.326 & 0.230 & 3.858 & 0.571 \\
\hline
\end{tabular}

Source: Eurostat, own calculations

The most significant decrease in tourist arrivals in CAE was in Hungary. Numbers from Hungary represent the whole year and indicate the drop off by almost $60 \%$ in total. In Hungary, the longest-lasting lockdown most probably caused a large decrease in domestic tourists to $57.1 \%$. International tourist arrivals declined in Hungary to $23 \%$ in comparison to 2019. 
The other countries published numbers only for a part of the year, and therefore the results can be better as they do not include autumn lockdown and Christmas time.

The least affected tourism was domestic tourism in the Czech Republic (drop down to 82.1\% in the first three quarters). Such numbers of tourist arrivals would enable majority of the hotels and businesses to survive. However, the change of tourists' structure leads to an uneven spread of the tourists among the regions. The worst data were in the destinations important for business travel, conferences, events, and the destinations important for international tourism (e.g., Prague).

The decline in all V4 countries was significant and approximately corresponding with the expected global numbers. Assumption of total world arrivals is the international arrivals decrease by $62 \%$, for domestic by $37 \%$ (WTTC, Europe Economic Impact from COVID-19, 2020).

The above analysed data are from hotel statistics. If we focus on UNWTO statistics about international arrivals in the first three quarters of 2020, we observe the largest decline in international arrivals in the Czech Republic $(-67.9 \%)$ and Hungary $(-59,1)$ (UNWTO, 2021b). UNWTO also monitors the tourism receipts (equivalent to tourism expenditures from WTTC and TSA). The results from the first two quarters of 2020 show the largest decrease in Slovakia $(-59 \%)$ and Hungary $(-42.7 \%)$. The decline in receipts is not in line with the arrivals decline and the tourists decline in CAE. These decreases may be due to different monitoring periods. Receipts' statistical data do not include data from the main tourist season (July and August).

\subsection{Potential of Domestic tourism for tourism survival and recovery}

In general, the COVID-19 pandemic will have a much more significant effect on tourism and tourism businesses than expected at the beginning of the pandemic in March/April 2020. Based on the summer experiences of 2020, the pandemic brought not only travel restrictions but also changes in customers' behaviour. Tourism will recover slowly, and the expected time to return to the 2019 level is 2023 - 2024. Domestic tourists were taking a leading position in the recovery of global tourism (OECD, 2020). However, destinations/countries need to note that domestic travellers, which are bringing direct or indirect economic effects, could not replace international travellers and international tourism expenditure in all countries.

This section aims to evaluate and compare the domestic tourism position and its potential for the survival of tourism businesses and further recovery of tourism in the V4 countries. This section builds on the knowledge and data collected in previous parts, brings own analysis, and uses new information sources.

Concerning tourism, the residents in V4 countries have lower financial funds than the international tourists usually have. Germany is an important source country for all V4 countries (first or second position in arrivals). The only lower-income counties among the first three are Ukraine (third for Poland) and Romania (first for Hungary).

From the comparison of residents' tourism expenditures (outbound) and income from inbound tourism, it is evident that outbound expenditures of residents, if being spent in the home country, could not replace the total outage of international tourism. In all V4 countries, there was a period when the countries allowed international arrivals. On the other hand, during the summer period 2020, the residents were also allowed to travel abroad. 
Tab. 7 Level to which the outbound expenditures can replace the inbound expenditures when spent in the home country

\begin{tabular}{|l|l|}
\hline & $\begin{array}{l}\text { Residents' outbound expenditure in comparison to inbound tourism } \\
\text { expenditures (\%) }\end{array}$ \\
\hline Czech Republic & 45,8 \\
\hline Slovakia & 53,3 \\
\hline Poland & 37,2 \\
\hline Hungary & 53,2 \\
\hline
\end{tabular}

Source: TSA of the individual countries, data from 2017

As shown in the table, the best position in this respect has domestic tourism in Slovakia and Hungary. The reasons are different - in Slovakia, the income from international tourism is relatively low; and in Hungary, the outbound expenditures are relatively high (it is the only V4 country with higher outbound than domestic tourism expenditures). Consumers' behavioral changes need to be considered: (1) the outbound expenditures are usually higher due to higher prices of the package tours, so the budget for domestic tourism can be lower on an individual bases and (2) many consumers have decided to postpone their foreign holidays until 2021 and not to spend the money saved on domestic holidays.

Analysing the CAE in table 5, a promising position of domestic tourism is in Poland. The gap to be covered by the domestic tourism after the outage of international arrivals is $20,1 \%$. The second country is Slovakia with the share of international tourists in CAE of $39 \%$. However, if we return to table 3 , despite the number of guests, domestic tourism does not generate as high income for the businesses and economy as the international tourists.

To evaluate the power of domestic tourism, the results from the $3^{\text {rd }}$ quarter of 2020 will be analysed. The main season in the V4 countries is summer, the travel restrictions were eased July - September 2020 and the accommodation facilities were open (the only exception is Hungary where the second lockdown started on the $1^{\text {st }}$ of September 2020). The state in summer 2020 can most likely illustrate the situation when international travel will be possible but still restricted.

Tab. 8 Tourists in CAE in the $3^{\text {rd }}$ quarter in 2020 (million)

\begin{tabular}{|l|l|l|l|l|l|l|}
\hline & $\begin{array}{l}\text { Tourist } \\
\text { arrivals at } \\
\text { CAE total }\end{array}$ & $\begin{array}{l}\text { Index } \\
2020 / \\
2019\end{array}$ & $\begin{array}{l}\text { International } \\
\text { tourist arrivals } \\
\text { at CAE }\end{array}$ & $\begin{array}{l}\text { Index } \\
2020 / \\
2019\end{array}$ & $\begin{array}{l}\text { Domestic } \\
\text { tourist arrivals } \\
\text { at CAE }\end{array}$ & $\begin{array}{l}\text { Index } \\
2020 / \\
2019\end{array}$ \\
\hline Czech Republic & 5.979 & 0.79 & 1.079 & 0.32 & 4.930 & 1,17 \\
\hline Slovakia & 1.632 & 0,78 & 0.395 & 0.46 & 1.239 & 1,00 \\
\hline Poland & 8.117 & 0.69 & 0.857 & 0.35 & 7.260 & 0.79 \\
\hline Hungary & 2.370 & 0.54 & 0.411 & 0.20 & 1.959 & 0.84 \\
\hline
\end{tabular}

Source: Statistical offices (www.czso.cz, www.statistics.sk, www.ksh.hu, https://stat.gov.pl)

The table is showing, what was the segments' reaction after eased travel restrictions. International tourism stayed at a low level in all countries. The best situation was in Slovakia ( $46 \%$ of the respective period in 2019). The reason could be that the Czech Republic is an important source country for Slovakia, and tourism between these two countries is very natural 
due to similar language, mixed families, a common history, etc. Poland came in second. However, the international tourists remained at the level of 35\% of 2019.

Domestic tourism reached better results. In the Czech Republic, domestic tourism has played an important role in the survival of businesses, with a $17 \%$ increase compared to the 3rd quarter of 2019. In Slovakia, domestic tourism reached the level of 2019 in the respective period. These two countries had the best results concerning the drop off of the total tourist numbers. The total number of guests in the CAE in both countries reached $80 \%$ of 2019 in the period under review. It can be a good sign for the businesses' survival and the potential tourism recovery.

For an illustration of international and domestic demand reaction, was used an online tool. Google Destination Insights offers an analysis based on relevant keywords. The next figures show the response of the demand based on the relevant search queries.

Fig. 2 Travel demand (international and domestic) in the Czech Republic, comparison of 2019 and 2020
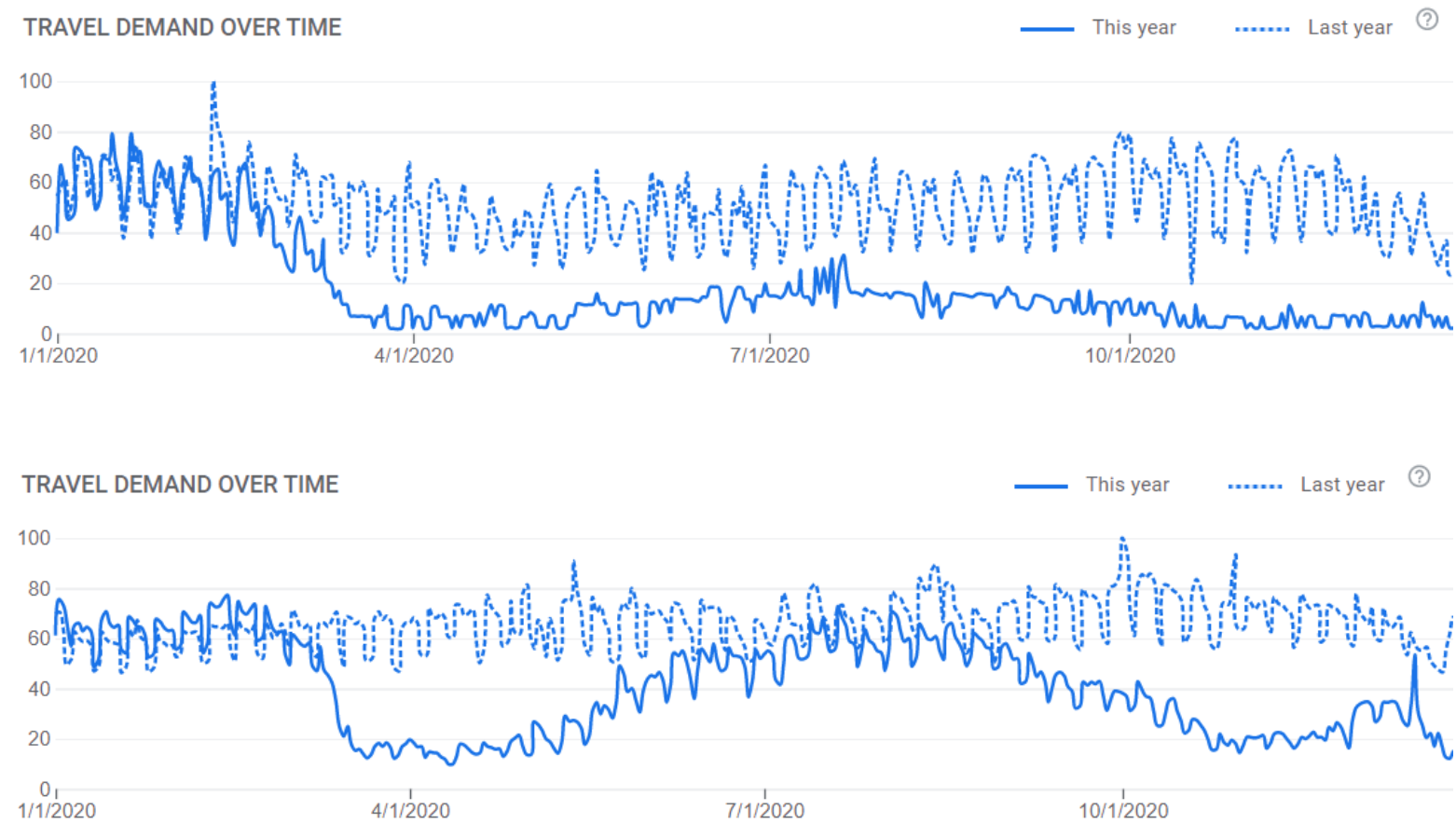

Source: https://destinationinsights.withgoogle.com/ (18.02.2020)

Fig. 3 Travel demand (domestic) in Slovakia, comparison of 2019 and 2020

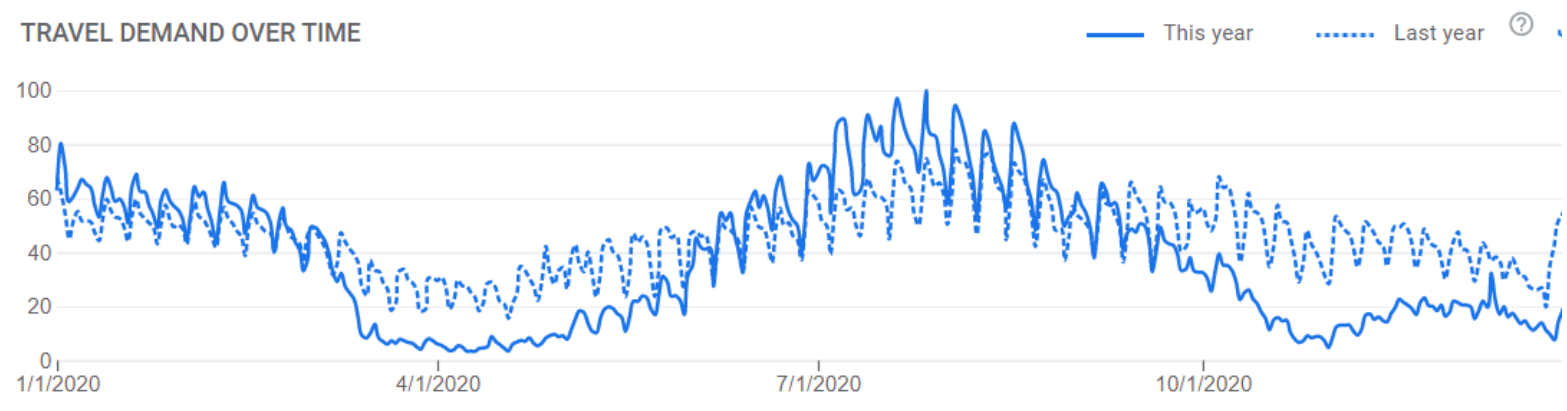

Source: https://destinationinsights.withgoogle.com/ (18.02.2020) 
Fig. 4 Travel demand (domestic) in Poland, comparison of 2019 and 2020

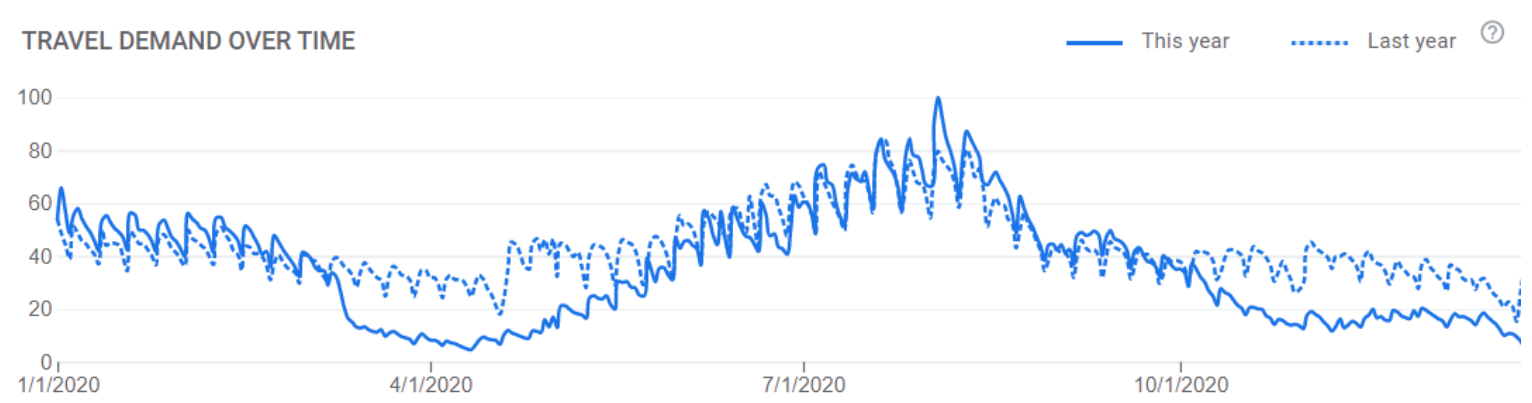

Source: https://destinationinsights.withgoogle.com/ (18.02.2020)

Fig. 5 Travel demand (domestic) in Hungary, comparison of 2019 and 2020

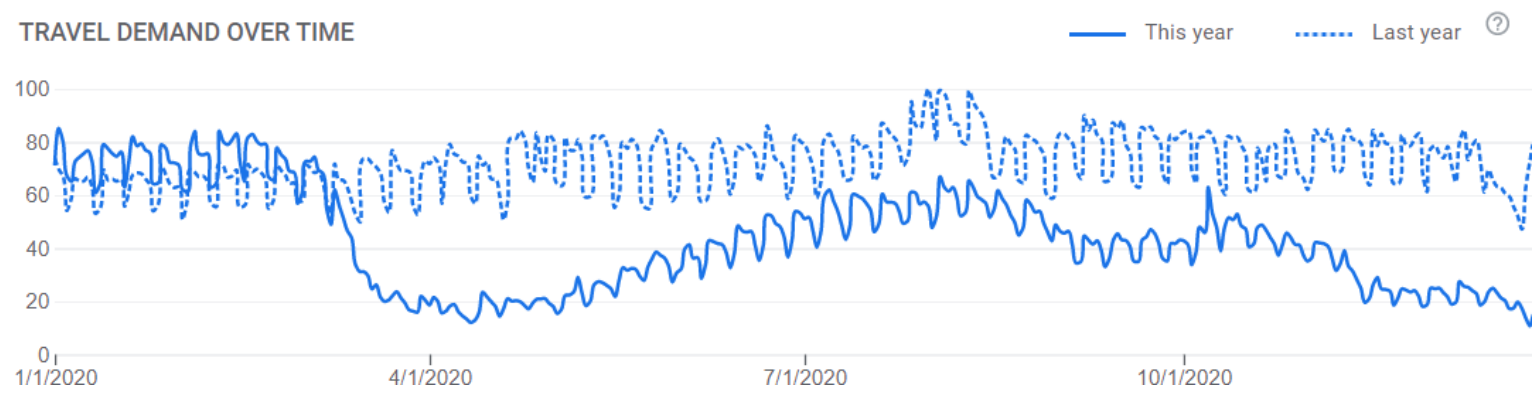

Source: https://destinationinsights.withgoogle.com/ (18.02.2020)

Because the international demand response in all V4 countries was very similar, so only figures from the Czech Republic are presented. The domestic demand, compared to 2019, is the highest in Slovakia, followed by Poland, the Czech Republic, and Hungary (with a significant decrease compared to 2019). We can see that, at the moment of opening the economy, the domestic demand quickly reached (and partially exceeded) the level of 2019 (except Hungary).

\subsection{Comparison of the potential of domestic tourism in V4 countries}

To compare the countries a simple scorecard with the placings of the countries in the individual criteria was created. As the scorecard presents the countries order, the lower is the number, the better is the country's position. As there is not enough literature to express the criteria's weight, the scorecard is only simple without the criteria's significance expression. The robustness of the scorecard was examined in two ways to assure the relevance of research results. Both approaches gave the same results. Therefore, the scorecard and the results can be considered relevant.

Tab. 9 Scorecard of the V4 countries

\begin{tabular}{|l|l|l|l|l|}
\hline & Czech Republic & Slovakia & Poland & Hungary \\
\hline GDP per capita & 1 & 2 & 4 & 3 \\
\hline $\begin{array}{l}\text { Distribution of travel and } \\
\text { tourism direct contribution } \\
\text { to GDP (international vs. } \\
\text { domestic) }\end{array}$ & 1 & 2 & 3 & 3 \\
\hline
\end{tabular}




\begin{tabular}{|l|l|l|l|l|}
\hline & Czech Republic & Slovakia & Poland & Hungary \\
\hline $\begin{array}{l}\text { Natural resources score } \\
\text { TTCI }\end{array}$ & 4 & 1 & 3 & 2 \\
\hline $\begin{array}{l}\text { Cultural resources score } \\
\text { TTCI }\end{array}$ & 2 & 4 & 1 & 3 \\
\hline $\begin{array}{l}\text { Share of domestic tourists } \\
\text { in CAE }\end{array}$ & 3 & 2 & 1 & 4 \\
\hline Tourism intensity & 4 & 1 & 2 & 3 \\
\hline $\begin{array}{l}\text { Outbound expenditure in } \\
\text { comparison to inbound } \\
\text { tourism expenditures }\end{array}$ & 3 & 1 & 4 & 2 \\
\hline $\begin{array}{l}\text { Total tourists in CAE in the } \\
\text { 3rd quarter (change) }\end{array}$ & 1 & 2 & 3 & 4 \\
\hline $\begin{array}{l}\text { Domestic tourists in CAE in } \\
\text { the 3rd quarter (change) }\end{array}$ & 1 & 2 & 4 & 3 \\
\hline $\begin{array}{l}\text { Domestic demand reaction } \\
\text { from Destination insights }\end{array}$ & 3 & 1 & 2 & 4 \\
\hline $\begin{array}{l}\text { Total score (weighted } \\
\text { score from the testing) }\end{array}$ & $23(147)$ & $18(112)$ & $27(179)$ & $31(195)$ \\
\hline
\end{tabular}

Source: own research

Based on the scorecard, it is evident that in Slovakia, domestic tourism has the best potential to help with the recovery and survival of businesses. The second-best position has domestic tourism in the Czech Republic. The third is Poland, and the weakest potential is in Hungary.

\section{CONCLUSION}

The main objective of the paper was to analyse and compare the domestic tourism potential in V4 countries as a factor of tourism survival, and recovery. The countries and their tourism were analysed from several perspectives and summarized in a simple scorecard. The paper contribution is the complex approach to the data, collection of the actual data from many sources, their comprehensive analysis, and putting the data into a broader context concerning domestic tourism.

The best situation regarding domestic tourism as a factor of tourism recovery and business survival is in Slovakia and the Czech Republic. However, even in these counties it is very unlikely, that the domestic tourism will replace outage of the international tourism in full scale. The financial receipts from international tourism play an important role for the economies.

The research was conducted with the available data at the time of writing. The domestic tourism is not researched in such details and it is very variable in different countries. The situation that the world is completely locked has never arose. Therefore, it was not possible to assign weight to individual criteria in the scorecard and the criteria are based on a combination of previous research, the available data and reasonable expectations. Nevertheless, the research brings a detailed picture of the situation in the V4 countries and a deep insight in the position and potential of domestic tourism. The future research can analyse the results from 2020 and 2021, it would be valuable to research the regional shifts and differences in the countries. The real results of tourism industry will be influenced also by the 
government support, current economy performance, unemployment change, availability of vaccination etc.

\section{REFERENCES}

AJMC staff (2021). A Timeline of COVID-19. A Development in 2020. AJMC (The American Journal of Managed Care). Retrieved 12 February 2021, from https://www.ajmc.com/view/atimeline-of-covid19-developments-in-2020

Athanasopoulos, G., \& Hyndman, R. J. (2008). Modelling and forecasting Australian domestic tourism. Tourism Management, 29, 19-31. https://doi.org/10.1016/j.tourman.2007.04.009

CDC, Centres for Disease Control and Prevention (2021). Retrieved 12 February 2021, from https://www.cdc.gov/coronavirus/2019-ncov/index.html

Czech Statistical Office (2020a) Guests in accommodation establishments total from beginning of the year 2020 till 30.09.2020 in the Czech Republic. Retrieved 05 February 2021, from https://www.czso.cz/csu/czso/ari/tourism-3rd-quarter-of-2020

Czech Statistical Office (2020b). International trade in goods (change of ownership) of the Czech Republic by CZ-CPA - quarterly data - 3rd quarter of 2020. Retrieved 18 November 2020, from https://www.czso.cz/csu/czso/external-trade-of-the-czech-republic-by-cz-cpaquarterly-data-3rd-quarter-of-2020.

Destination Insights with Google. Monitoring Travel Trends. Retrieved 18 February 2021 from https://destinationinsights. withgoogle.com/

Diaz Parra, I., \& Jover, J. (2020). Overtourism, place alientation and the right to the city: insights from the historic centre of Seville, Spain. Journal of Sustainable Tourism, 29(3), 1-18. https://doi.org/10.1080/09669582.2020.1717504

Czech Statistical Office (2021). Capacity of accommodation establishments by category. Retrieved $04 \quad$ February 2021, from https://vdb.czso.cz/vdbvo2/faces/en/index.jsf?page=statistiky\&katalog=31742

EC, European Commission (2020a). Communication from the Commission-Temporary Framework for State aid measures to support the economy in the current COVID-19 outbreak. Brussels, 19.3.2020. C(2020)1863 final. Retrieved 12 February 2021, from https://eurlex.europa.eu/legal-content/EN/TXT/?uri=0J\%3AJOC_2020_091_I_0001

EC, European Commission (2020b). Tourism and Transport: Commission 's guidance on how to safely resume travel and reboot Europe's tourism in 2020 and beyond. Press release. 13 May 2020. Brussels, European Commission. Retrieved 12 February 2021, from https://ec.europa.eu/commission/presscorner/detail/en/ip_20_854

ETC, European Travel Commission (2020a). European Commission Guidelines are paving the way to recovery for the European tourism sector from the COVID-19 crisis. Brussels, 20 May 2020.

The European Tourism Manifesto alliance (2020). Retrieved 12 February 2021, from https://tourismmanifesto.eu/wp-content/uploads/2020/05/Statement_follow-up-ECcommunication.pdf

ETC, European Travel Commission (2020b). Handbook on COVID-19 recovery strategies for National Tourism Organisations. September 2020. Brussels. ETC Marketing Intelligence.ISBN:978-92-95107-37-3. Retrieved 12 February 2021, from https://etccorporate.org/reports/handbook-on-covid-19-recovery-strategies-for-national-tourismorganisations/ 
ETC, European Travel Commission (2021). Monitoring sentiment for domestic and intraEuropean travel - Wave 4. January 2021. Brussels. European Travel Commission. ISBN:97892-95-10742-7

Euromonitor International (2021). EMI Future Outlook: Looking Beyond COVID-19 for Recovery, January 2021. EMI Presentations of Caroline Bremmer, Head of Travel Research. Available on request and retrieved 12 February 2021, from https://www.euromonitor.com/locations

Eurostat (2019). Tourism Satellite Accounts in Europe, 2019 edition. Retrieved 04 February 2021, from https://ec.europa.eu/eurostat/documents/7870049/10293066/KS-FT-19-007-ENN.pdf/f9cdc4cc-882b-5e29-03b1-f2cee82ec59d

EUROSTAT (2020) Number of trips by country / world region of destination. Retrieved 16 February 2021 , from https://appsso.eurostat.ec.europa.eu/nui/show.do?dataset=tour_dem_ttw\&lang=en

EUROSTAT (2021) Nights spent at tourist accommodation establishments, Retrieved 18 February 2021 , from https://appsso.eurostat.ec.europa.eu/nui/show.do?dataset=tour_occ_ninat\&lang=en

Garin-Munoz, T. (2009). Tourism in Galicia: domestic and foreign demand. Tourism Economics, 15(4), 753-769. https://doi.org/10.5367/000000009789955107

Gössling, C.,Scott, \& D., Hall, M.C. (2020). Pandemic, tourism and global change: a rapid assessment of COVID-19. Journal of Sustainable Tourism, 29 (1), 1-20.

https://doi.org/10.1080/09669582.2020.1758708

Holloway, C., \& Humpreys, C. (2012). The Business of Tourism (9 th $^{\text {th }}$ ed.) Harlow: Person Education Ltd.

Horner, S., \& Swarbrooke, J. (1996). Marketing Tourism, Hospitality and Leisure in Europe. London: International Thomson Business Press.

Houska, P., \& Petru, Z. (2019). Evropska ekonomicka integrace a cestovni ruch. Praha: Idea servis.(in Czech)

Hungarian Central Statistical Office (2020). The number of inbound trips to Hungary and the related expenditures. Retrieved 04 February 2021, from http://www.ksh.hu/docs/eng/xstadat/xstadat_annual/i_ogt002a.html

Hungarian Central Statistical Office (2021) Tourist arrivals at commercial accommodation establishments in Hungary. Retrieved 05 February 2021, from https://www.ksh.hu/docs/eng/xstadat/xstadat_infra/e_oga003c.html?down=657

Knoema (undated) Hungary - Contribution of travel and tourism to GDP as a share of GDP. Retrieved 04 February 2021, from https://knoema.com/atlas/Hungary/topics/Tourism/Traveland-Tourism-Total-Contribution-to-GDP/Contribution-of-travel-and-tourism-to-GDP-percentof-GDP

Knoema (undated). Czech Republic - Contribution of travel and tourism to GDP as a share of GDP. Retrieved 04 February 2021, from https://knoema.com/atlas/CzechRepublic/topics/Tourism/Travel-and-Tourism-Total-Contribution-to-GDP/Contribution-oftravel-and-tourism-to-GDP-percent-of-GDP

Knoema (undated). Poland - Contribution of travel and tourism to GDP as a share of GDP. Retrieved 04 February 2021, from https://knoema.com/atlas/Poland/topics/Tourism/Traveland-Tourism-Total-Contribution-to-GDP/Contribution-of-travel-and-tourism-to-GDP-percentof-GDP 
Lim, C. (1997). Review of international tourism demand models. Annals of Tourism research, 24 (4), 835-849. https://doi.org/10.1016/S0160-7383(97)00049-2

List of European countries by GDP (Nominal) per capita in \$. Retrieved 04 February 2021, from http://statisticstimes.com/economy/european-countries-by-gdp-per-capita.php

Massidda, C., \& Etzo, I. (2012). The determinants of Italian domestic tourism: A panel data analysis. Tourism Management, 33 (3), 603-610.

https://doi.org/10.1016/j.tourman.2011.06.017

MV ČR (2019). Ministerstvo vnitra ČR (Ministry of Internal Affairs of the Czech Republic) Retrieved 11 February 2021 from (in Czech) https://www.mvcr.cz/clanek/mezinarodniorganizace-a-vs-visegradska-ctyrka.aspx

OECD (2020). OECD Tourism Trends and Policies 2020. https://doi.org/10.1787/6b47b985-en. Palatkova, M. (2006). Marketingova strategie destinace cestovniho ruchu. Praha: Grada Publishing a.s.

Petru, Z. (2007). Zaklady cestovniho ruchu (2 ${ }^{\text {nd }}$ ed.). Praha: Idea servis.

Seddighi, H. R., \& Shearing, D. F. (1997). The demand for tourism in North East England with special reference to Northumbria: an empirical analysis. Tourism Management, 18(8), 499511. https://doi.org/10.1016/S0261-5177(97)00072-1

Slovakia - Contribution of travel and tourism to GDP as a share of GDP. Retrieved 04 February 2021, from https://knoema.com/atlas/Slovakia/topics/Tourism/Travel-and-Tourism-TotalContribution-to-GDP/Contribution-of-travel-and-tourism-to-GDP-percent-of-GDP

Statista (2020a). Number of arrivals in tourist accommodation in Poland from 2006 to 2018 (in millions) Retrieved 04 February 2021, from https://www.statista.com/statistics/413249/number-of-arrivals-spent-in-short-stayaccommodation-in-poland/

Statista (2020b). Number of arrivals in tourist accommodation in Slovakia from 2006 to $2019 *$ (in millions) Retrieved 04 February 2021, from https://www.statista.com/statistics/413258/number-of-arrivals-spent-in-short-stayaccommodation-in-slovakia/

Statista (2020c). Number of international tourists visiting Poland from 2018 to 2019, by country of residence (in 1,000s). Retrieved 04 February 2021, from https://www.statista.com/statistics/446629/leading-international-travel-markets-for-poland/

Statista (2020d). Number of overnight stays in travel accommodation in Poland between 2007 and 2018 (in millions), Retrieved 18 February, 2021 from https://www.statista.com/statistics/413172/number-of-nights-spent-in-short-stayaccommodation-in-poland/

Statista (2020e). Average number of inbound and domestic visitors per inhabitant in Hungary from 2008 to 2019. Retrieved 12 February 2021, from https://www.statista.com/statistics/1009305/hungary-inbound-domestic-visitor-perpopulation/

Statista (2020f). Distribution of travel and tourism's direct contribution to GDP in Hungary in 2017, by domestic and foreign spending*. Retrieved 04 February 2021, from https://www.statista.com/statistics/978504/travel-and-tourism-gdp-contribution-share-byforeign-domestic-hungary/ 
Statista (2020g). Gross domestic product (GDP) at current market prices of selected European countries in 2019 (in billion euros). Retrieved 04 February 2021, from https://www.statista.com/statistics/685925/gdp-of-european-countries/

Statista (2020h). Unemployment rate in member states of the European Union in July 2020 (seasonally adjusted). $\quad$ Retrieved $\quad$ February $13 \quad 2021$ from https://www.statista.com/statistics/268830/unemployment-rate-in-eu-countries/

Statista (2021a). Incidence of coronavirus (COVID-19) deaths in the European Economic Area and the United Kingdom as of January 31, 2021, by country (per 100,000 population). Retrieved 04 February 2021, from https://www.statista.com/statistics/1111779/coronavirusdeath-rate-europe-by-country/

Statista (2021b). Number of coronavirus (COVID-19) cases in Europe as of January 31, 2021, by country. Retrieved 04 February 2021, from https://www.statista.com/statistics/1104837/coronavirus-cases-europe-by-country/

Statista (2021c). Population of selected European countries in 2020 (in million inhabitants). Retrieved 04 February 2021, from https://www.statista.com/statistics/685846/population-ofselected-european-countries/ Retrieved 04 February 2021, from https://wttc.org/Research/Economic-Impact

Statistical Office of the Slovak Republic (2020a). Tourism development in accommodation establishments in the SR. Retrieved 16 February 2021, from https://slovak.statistics.sk/wps/portal/ext/themes/sectoral/tourism/publications/!ut/p/z0/04_ Sj9CPykssy0xPLMnMz0vMAfIjo8ziw3wCLycDB0N3M1DDA08_fyCQ8MsAo39A0z1g1Pz9AuyHR UBdV2u2A!!/

Statistical Office of the Slovak Republic. (2020b). Development of tourism in accommodation establishments in the $S R$ in August 2020. Retrieved 05 February 2021, from https://slovak.statistics.sk/wps/portal/ext/products/informationmessages/inf_sprava_detail/! ut/p/z1/tZLNbuMgFIWfZRZe4ntjcCDd2ZUaJ40idaJMazYVxjhxG2PHpvZOnn5INZuR-

qNZDBtA93D4LgeQ8ADSqrE-KFe3Vp38Ppfzxzu-Emk6SxDTDcXV-na3za5vouUhh8gQWrrOneEvC0GdSTGktpWRD27AP2i7RvvNIpDhq5X42uA42Dcs58LEaEodUVoWQjCYqVIo WNFIGJGRJUqKoYX-

07XJeQ6KjIIZUF0LDhhs1ITQXVM5pwqtjBULCoO91_xSI_GD0aCsDPWe8g32fUyyRjfIIrNMsZVku 2_L-4oxYT-EXzik3sO_iHHzIOOtZlgby-vc4LdP7aZIaxB1kUTTroJMeSCI-

VcsIgt5jGII9zqp_NZJj6c1jrz08HD_0jH35PYgooDyN5Upjd9-

NL7b3N0rhuuAgxwmqbw0LaHkwl12wTvHjm2g-

f7Wwld0wj6StbZr3RLIvfCxfm336FXsGI!/dz/d5/L2dBISEvZ0FBIS9nQSEh/

Statistics Poland (2020). Tourism in 2019. Retrieved 04 February 2021, from https://stat.gov.pl/en/topics/culture-tourism-sport/tourism/tourism-in-2019,1,17.html

Statistics Poland (2021). Tourists (domestic and foreign) in tourist accommodation establishments possesing 10 or more bed places in 2020 in Poland. Retrieved 05 February 2021, from https://stat.gov.pl/en/topics/culture-tourism-sport/tourism/tourists-in-touristaccommodation-establishments-november-2020,3,38.html?pdf=1

StatisticsTimes (2020) GDP (Nominal) in European countries in 2019 (in billions of \$). Retrieved 04 February 2021, from http://statisticstimes.com/economy/european-countries-by-gdp.php

Swarbrook, J., \& Horner, S. (2007). Consumer Behaviour in Tourism. London: ButterworthHeinemann. https://doi.org/10.4324/9780080466958

UNWTO (2020a). International Tourism Highlights, 2020 Edition. Retrieved 05 February 2021 from: https://www.e-unwto.org/doi/book/10.18111/9789284422456 
UNWTO (2020b). COVID-19 Tourism Recovery Technical Assistance Package. Retrieved 12 February 2021 from https://webunwto.s3.eu-west-1.amazonaws.com/s3fs-public/202005/COVID-19-Tourism-Recovery-TA-Package_8\%20May-2020.pdf+

UNWTO (2021a). 2020: Worst Year in Tourism History with 1 Billion Fewer International Arrivals. Retrieved 05 February 2021 from https://www.unwto.org/news/2020-worst-year-intourism-history-with-1-billion-fewer-international-arrivals

UNWTO (2021b). UNWTO World Tourism Barometer and Statistical Annex, January 2021, Retrieved 05 February 2021 from abstract https://www.eunwto.org/doi/abs/10.18111/wtobarometereng.2021.19.1.1

UNWTO (2021c). International Tourism Highlights, 2020 Edition, UNWTO, Madrid, https://doi.org/10.18111/9789284422456.

Visegrad Group. https://www.visegradgroup.eu/about

WHO, World Health Organization (2021a). Weekly epidemiological update- 5 January, 20921data as of January 2021. Retrieved 12 February 2021 from https://www.who.int/publications/m

WHO, World Health Organization (2021b). https://www.who.int/travel-advice

World Bank. Population, Retrieved 12 February 2021 from https://data.worldbank.org/indicator/SP.POP.TOTL

World Economic Forum (2019). Travel \& Tourism Competitiveness Report 2019. Retrieved 04 February 2021, from https://reports.weforum.org/travel-and-tourism-competitiveness-report2019/rankings/

WTTC, World Travel \& Tourism Council (2017). Understanding the Critical Issues for the Future of Travel and Tourism. Retrieved 10 February, 2021 from https://www.americansforthearts.org/sites/default/files/issuetourism.pdf

WTTC, World Travel \& Tourism Council (2020a). Annual Research: Key Highlights, Czech Republic, Hungary, Poland, Slovakia.

WTTC, World Travel \& Tourism Council (2020b). 'Safe Travels': Global Protocols \& Stamp for the New Normal. Retrieved 12 February 2021 from https://wttc.org/COVID-19/Safe-TravelsGlobal-Protocols-Stamp

WTTC, World Travel \& Tourism Council (2020c): Recovery Scenarios 2020 \& Economic Impact from COVID-19 -November 2020. https://wttc.org/Research/Economic-Impact/RecoveryScenarios

WTTC, World Travel \& Tourism Council (2020d). Travel \& Tourism - Global Economic Impact \& Trends 2020 - May 2020. Retrieved 12 February 2021, from https://wttc.org/Research/Economic-Impact 